\title{
A case study from the southern Cape linefishery 1: The difficulty of fishing in a changing world
}

\author{
AUTHORS: \\ Louise C. Gammage ${ }^{1}$ iD \\ Astrid Jarre ${ }^{1}$ \\ Charles Mather ${ }^{2,3}$ iD

\section{AFFILIATIONS:} \\ ${ }^{1}$ Marine Research (Ma-Re) \\ Institute, Department of \\ Biological Sciences, University \\ of Cape Town, Cape Town, \\ South Africa \\ ${ }^{2}$ Department of Geography, \\ Memorial University, \\ St John's, Canada \\ 'Department of Geography, \\ Environmental Management and \\ Energy Studies, University of \\ Johannesburg, Johannesburg, \\ South Africa
}

\section{CORRESPONDENCE TO: \\ Louise Gammage}

\section{EMAIL:}

louisegammage@gmail.com

\section{DATES:}

Received: 25 Aug. 2016

Revised: 24 Nov. 2016

Accepted: 24 Jan. 2017

\section{KEYWORDS:}

vulnerability; stressors; climate change:

small-scale fisheries;

social-ecological systems

\section{HOW TO CITE:}

Gammage LC, Jarre A, Mather C. A case study from the southern Cape linefishery 1 : The difficulty of fishing in a changing world. S Afr J Sci. 2017;113(5/6), Art. \#2016-0252, 8 pages. http://dx.doi.org/10.17159/ sajs.2017/20160252

\section{ARTICLE INCLUDES: \\ $\times$ Supplementary material \\ $\times$ Data set}

\section{FUNDING:}

DST (SARChl Marine Ecology and Fisheries) through the National Research Foundation (South Africa)

(C) 2017. The Author(s). Published under a Creative Commons Attribution Licence.
Variability on multiple temporal and spatial scales exposes fishers and fishing communities to multiple stressors. The impact and interplay of these stressors need to be considered to improve our understanding of social-ecological linkages if sustainable livelihoods are to be promoted. To this end, participant-led research was conducted in the small-scale traditional commercial linefishery of the southern Cape (South Africa) between Witsand and Mossel Bay. Knowledge and perceptions regarding stressors responsible for changes in the social-ecological system, which ultimately affect the fishers' ability to fish successfully, were recorded using semi-formal interviews and focus groups with 50 participants. The results presented not only offer valuable insights into the day-to-day experiences of these fishers, but also expose knowledge gaps that exist in micro-scale interactions influencing the fishery system. An analysis of various stressors is presented, which includes the impacts of and responses to climate variability; challenges presented by fisheries policies and regulatory frameworks; social and economic considerations; inadequate infrastructure; and general political considerations. The development of a more comprehensive understanding of stressors that affect the social-ecological system at various scales provides valuable insights into a fishery system that is currently not well described, and provides the basis for analyses into vulnerability and resilience.

\section{Significance:}

- Understanding the impact and interplay of stressors at multiple scales is important if sustainable livelihoods are to be promoted.

- This research provides insight into the day-to-day experiences of fishers whilst exposing knowledge gaps that exist at a micro-scale.

\section{Introduction}

The Benguela Current Large Marine Ecosystem is an eastern boundary current system dominated by coastal upwelling. It is a very productive region and sustains important fisheries for Angola, Namibia and South Africa. ${ }^{1}$ The Benguela Current Large Marine Ecosystem displays a high amount of variability and consists of four shelf subsystems, including the Agulhas Bank subsystem off the southern Cape coast., ${ }^{2,3}$ The roughly triangular Agulhas Bank extends approximately $117 \mathrm{~km}$ (63 nautical miles) off Cape Agulhas, within the South African exclusive economic zone. This study focused on the small-scale commercial linefishery that operates in the inshore area of the Agulhas Bank and primarily targets silver kob (Argyrosomus inodorus). The traditional linefishery in South Africa is a boat-based, multi-user, multi-species and multi-area fishery that targets 50 commercially important fish species. ${ }^{4,5}$ Rights allocation in this sector is done in accordance with a total applied effort, which limits the amount of effort that may be expended. The first allocation of fishing rights in line with the current total applied effort took place in 2003. This allocation, fraught with challenges, resulted in 450 rights granted. Crew not included in the initial allocation were subsequently granted interim relief permits for subsistence purposes. ${ }^{6}$

A range of anthropogenic stressors such as resource scarcity, poor socio-economic conditions, and policy and regulatory challenges affect the inshore social-ecological system of the southern Cape. These stressors cause commercial small-scale fishers and their communities to become increasingly vulnerable to local and global changes in the fishery system. ${ }^{7}$ In future, fishers will need to cope with and adapt to multi-scalar social and ecological changes. Their communities will be required to enhance their strategies to achieve resilient livelihoods. In this paper, we discuss the stressors that make these fishers vulnerable to change. In conjunction, we provide analyses and discussion of the current strategies employed by fishers in reaction to change caused by these stressors in a paired paper. ${ }^{8}$

Recent research has illustrated that stressors that give rise to fishers' vulnerability to change commonly encompass a wide range of factors that include micro- and macro-level changes to social and environmental systems. ${ }^{9,10}$ Studies of stressors highlight situational and contextual factors and their relative importance in the configuration of the local social developmental context. ${ }^{4}$ The impact of responses is shaped and mediated by social, cultural, economic, technological, political and institutional factors. ${ }^{10}$ Whilst vulnerability has been defined in numerous ways by various authors, ${ }^{7,11-13}$ studies carried out in the African context emphasise the need to capture the changing nature of risks. ${ }^{8,10}$ Southern African studies ${ }^{11,14-17}$ have shown that there are clear risks posed to individuals, households and communities that are unable to cope with multiple stressors, let alone adapt to them. Interactions between stressors may have unexpected outcomes for both human well-being and livelihoods with serious implications for efforts to reduce vulnerability of resource users. Stressors and interactions amongst them have the potential to remain hidden, thereby spreading across various scales and leaving social units subject to the risk of double and/or multiple exposure. ${ }^{18}$ This spread can result in the effect of a stressor being felt more than once through different pathways. 
Understanding exposure and sensitivity of stressors across scales, paired with effective action, could be key to effectively reducing the vulnerability of fishers. To ascertain how people are affected by, and unable to cope with, stressors, it is necessary to move beyond linear vulnerability assessments that are based on processes and outcomes. ${ }^{10}$ Turner et al. ${ }^{19}$ propose a sustainability/vulnerability framework for which to analyse elements of a bounded system at a particular scale. ${ }^{7}$ Cutter et al. ${ }^{20}$ suggest that a place-based approach can be used to position local vulnerability within the larger contexts to compliment the approach outlined by Turner et al..$^{19}$ The framework proposed by Turner et al. ${ }^{19}$ maintains that certain elements are integral to an extended vulnerability and sustainability assessment; these elements must consequently be included in any vulnerability analysis that seeks to encourage sustainability.

\section{Research area and methodology}

Participant-led research was carried out in six towns located within a 155-km stretch of the southern Cape coastline: Mossel Bay, Gouritsmond, Melkhoutfontein, Still Bay, Vermaaklikheid and Witsand (Figure 1). Interviews were conducted between July 2013 and February 2014 with 50 individual participants comprising skippers, boat owners, crew, members from associated industry, as well as spouses/partners. Both one-on-one, semi-structured interviews and several group interviews of varying sizes were conducted. Group interviews were favoured by some participants as they felt more comfortable in that setting. For the groups, participant details and responses were recorded as individual responses with only those attendees that actively participated throughout and on all topics recorded as a participant. No group consensus was reached or required and responses were captured and coded on the scale of the individual in the analysis. The sample size of 50 represented approximately $30 \%$ of the total number of possible participants from the area. This number (150) was derived from data obtained from the Department of Agriculture, Forestry and Fisheries (DAFF) from active commercial handline fishing rights for 2011. Participants dictated the time, duration and format of interviews according to the integrity of a participant-led research process. Interviews and discussions were audio recorded and later transcribed with participants' permission and anonymity was maintained. Data were analysed by means of thematic analysis.
Despite efforts to ensure the even distribution of participants in terms of role and geographical location, this goal was not attainable (Table 1). However, the uneven distribution was not a hindrance as participant responses remained consistent throughout the research. The uneven distribution is particularly evident in the relatively small numbers of crew members who participated. Many skippers/boat owners and right holders functioned as gatekeepers, who at times inadvertently restricted access to their crew. This restriction, along with other factors such as the gender bias and a natural distrust of 'outsiders', made it difficult to approach the crew members. However, crew members are also more mobile within the sector than other role players and many (per participants) were not present in the area at the time of the research.

\section{Results and discussion}

Participants provided information on factors that impede their ability to fish successfully. Table 2 reflects stressors identified by participants in response to the question 'What are those things that make it difficult for you to fish successfully?'. Three major groupings of stressors were identified during thematic data analyses, namely major, mid-range and minor stressors. Major stressors were those mentioned by more than $80 \%$ of participants. These stressors consisted of policy and regulation, changes in the natural environment, as well as the impact of the inshore trawl fishery on the local linefishery. Mid-range stressors were mentioned by $50 \%$ to $80 \%$ of respondents and included stressors related to enforcement and implementation of policy, economic factors and 'political' issues amongst fishers. Minor stressors were mentioned by less than half of the participants and consisted of geography of the local area, infrastructure, social factors, lack of knowledge (for example in financial planning), fishing methods, and impacts of other marine species (e.g. seals and sharks). Some of the minor stressors identified were unique to specific towns, e.g. geographical location (remoteness) that was specific to Vermaaklikheid.

Stressors are discussed below in the context of the three broad groups outlined in Table 2, with attention to the major stressors. These stressors speak to changes observed in the natural (sub-) system followed by those that emanate from the human-social (sub-) system.

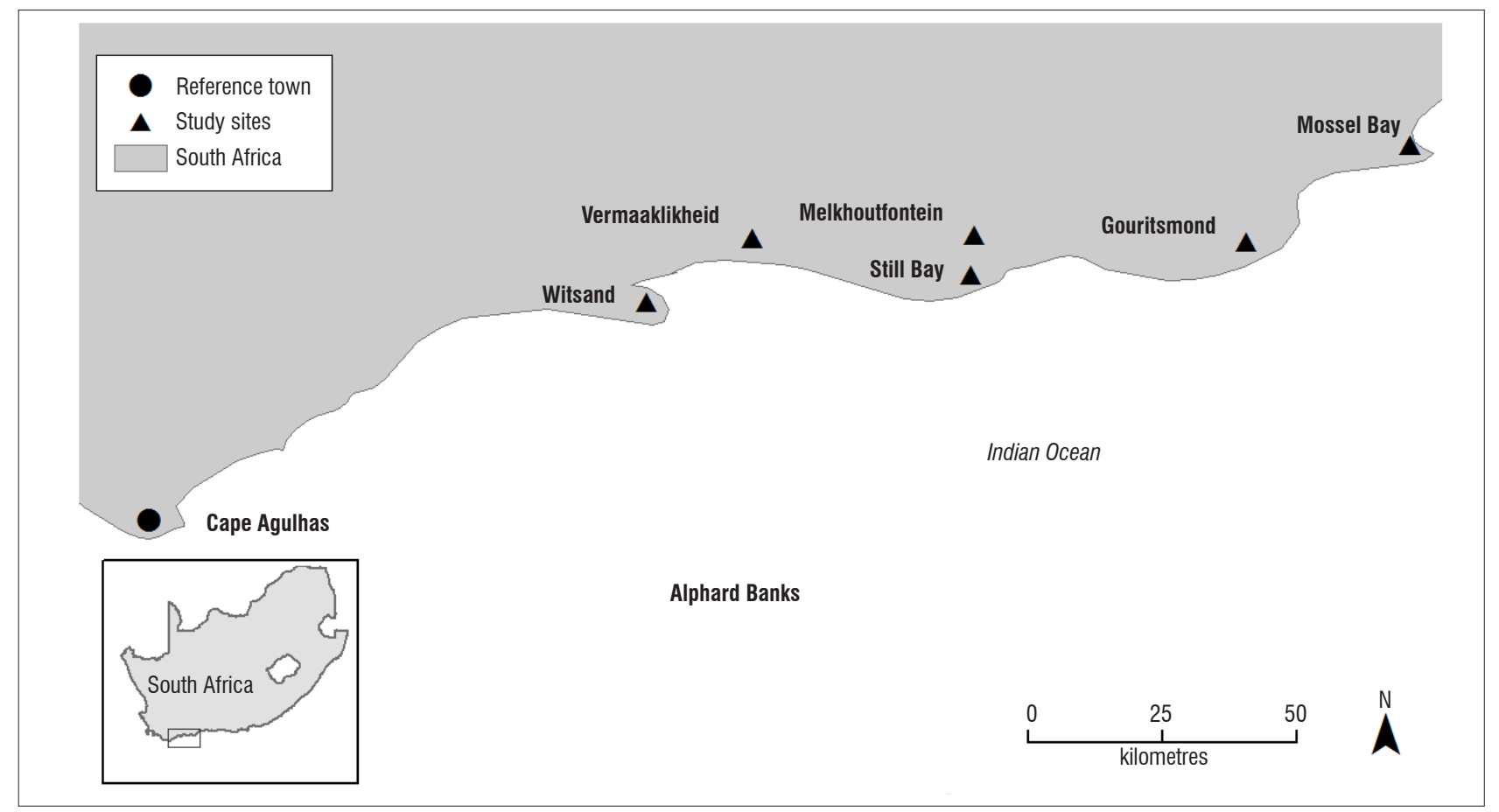

Figure 1: Map of the research area in the southern Cape. The map shows the six towns that were directly involved in the study: Mossel Bay, Gouritsmond, Still Bay, Melkhoutfontein, Vermaaklikheid and Witsand. 
Table 1: Composition of the total group of participants

\begin{tabular}{l|c|c|c}
\hline \hline \multicolumn{1}{c|}{ Town } & \multicolumn{3}{c}{ Role } \\
\hline \hline Mossel Bay & Skipper/boat owner and/or rights holder & Crew & Associated industry \\
\hline Gouritsmond & 5 & 0 & 0 \\
\hline Melkhoutfontein & 1 & 0 & 0 \\
\hline Still Bay & 2 & 3 & 1 \\
\hline Vermaaklikheid & 7 & 1 & 0 \\
\hline Witsand & 3 & 9 & 2 \\
\hline Total & 1 & 0 & 0 \\
\hline
\end{tabular}

Table 2: Stressors identified by participants. Stressors identified by $80 \%$ or more of all participants were termed 'major', those identified by $50-79 \%$ 'mid-range' and by less than half of the participants as 'minor'.

\begin{tabular}{l|c|c|c|c}
\hline \hline \multicolumn{2}{c|}{ Major stressors } & \multicolumn{1}{c|}{ Mid-range stressors } & Minor stressors \\
\hline \hline \multicolumn{1}{c|}{ Stressor } & $\%$ & Stressor & $\%$ & Stressor \\
\hline Policy and regulation & $92 \%$ & Enforcement and implementation of policy & $76 \%$ & Geography of area \\
\hline Climate variation & $90 \%$ & Economic (in terms of capital) & $76 \%$ & Inadequate infrastructure \\
\hline Other fishing sectors (such as inshore trawl) & $84 \%$ & 'Political issues' (amongst fishers and sector) & $76 \%$ & Social factors \\
\hline & & Socio-economic & $70 \%$ & $\begin{array}{l}\text { Lack of knowledge (financial planning, } \\
\text { literacy level, etc.) }\end{array}$ \\
\cline { 3 - 5 } & & & $44 \%$ & Fishing methods \\
\hline
\end{tabular}

\section{Variability in the natural system}

Recognising that observed changes in the natural system occur at various temporal scales, reported daily impacts show a link between the ability of fishers to proceed to sea (climate variation and its effects on weather) and the abundance and behaviour of target species in areas of operation. Importantly, interview data suggest that no single driver of change is identifiable, but rather a collection of stressors that indicate high variability and/or change at various temporal and spatial scales.

Globally, large-scale changes in the marine environment can manifest as changes in sea surface temperature (SST), large-scale circulation patterns, stratification and nutrient availability. ${ }^{21}$ Non-climatic stressors linked to climate change include ocean acidification, pollution, habitat alteration and destruction, coastal eutrophication, the spread of invasive species and fishing pressures..$^{21}$ It is difficult to predict how different marine habitats respond to these stressors, especially at smaller, localised scales. While quantified data are available on large scales for some of these stressors, regional impacts are not easily identifiable or quantifiable at smaller, localised scales. ${ }^{21,22}$ Seasonal, inter-annual and decadal-scale variability in winds, SST, bottom oxygen and primary productivity have been documented for the Agulhas Bank.,23-25 Inshore systems are particularly exposed to human-mediated pressures that drive change over multiple spatial and temporal scales, affecting not only the marine environment but also the fishing communities that interact with them. . $2,26-28^{2}$

\section{Physical variability}

Participant observations indicated a general warming trend (air and/ or SST) with unseasonable prevailing wind conditions (winds arriving late and shifts between southeasterly and southwesterly winds). Shifts in wind conditions resulted in a deterioration of sea state and fewer available sea days. Prevailing economic conditions (price of fuel and bait) forced fishers to go to sea on days on which weather conditions were most favourable, as the likelihood of landing profitable catches was higher, resulting in a further reduction of sea days.

Throughout the study, concerns about environmental stressors were framed in terms of climate change. Participants did not give a clear indication whether the effects of other stressors/drivers within the system were accounted for when such evaluations were made. There was some variation within the participants' responses as to the nature of the variability, making it difficult to determine the exact temporal scale on which the variation was observed. ${ }^{21}$

A small number of 'older generation' participants (older than 50 years) explicitly indicated that they regarded the observed variation as being cyclic. Other participants indicated that although cyclic variation had been previously observed, present events appeared to be increasingly extreme in nature (higher maxima of temperature and wind speeds). This observation is consistent with general climate change expectations in which increases in maxima within normal variability ranges are predicted. ${ }^{29}$ However, these participant observations have not been observed in data sets of geostrophic winds and subsequent calculated upwelling on the Agulhas Bank. ${ }^{25}$ The majority of participants highlighted a direct relationship between diminishing kob catches (2-3 years prior to this research) and changes/variability in the local climate. However, it was unclear how much participants understood about global and regional climate change and how much of their positive response was driven by media information.

Failure to accurately identify or recognise climate drivers within local contexts may hamper fishers' ability to respond adequately to this stressor. Research conducted in Thailand by Bennett et al..$^{30}$ found that a general lack of knowledge of climate change meant that individuals and households were more likely to react to stressors instead of adapting 
via active management of the risks and/or planning for climate change. This uncertainty regarding the source, depth and context of the fishers' knowledge of climate change warrants further research.

The hydrology of the Agulhas Bank is primarily driven by the wind regime, the Agulhas Current that runs along the shelf break, as well as the seasonal overturn of shelf waters. ${ }^{3}$ Analysis by Rouault et al. ${ }^{31}$ (using satellite and modelling studies) indicates a strengthening of the Agulhas Current flow over the past 25 years, resulting in warmer offshore water. Subsequent analyses conducted by Rouault et al..$^{32}$ using in-situ and satellite SSTs plus SSTs simulated by sea-ice coverage confirmed offshore warming and inshore cooling which corroborated findings by Roy et al. ${ }^{33}$ However, more recent analysis conducted using Pathfinder data (version 5.2) does not confirm these results, indicating instead a consistent warming trend inshore and over the central Agulhas Bank across all seasons, with general warming most distinctive in the early austral summer months. ${ }^{5}$ These recent findings are supported by many of the participants' observations of SST increase in the recent past.

There is larger disagreement between signals of different scientific data sets for the Agulhas Bank than for the other subsystems of the Benguela. ${ }^{3}$ Furthermore, scientific data are not available to characterise ocean temperature variability and/or trends at the bay scale. This makes it problematic for scientists to relate to changes in temperature observed by participants. This discrepancy draws attention to a scale mismatch of data which is an example of how scale mismatches can result in knowledge gaps. ${ }^{34}$

\section{Biological variability}

Kob is not the only linefish species available for exploitation in the area, although it is regarded as the most commercially viable. Other species like silvers/carpenters (Argyrozona argyrozona) and reef fish such as red roman (Chrysoblephus laticeps) are targeted in the absence of kob. Although close to the productive fishing water of the southwestern Cape, fishers in this area cannot commercially exploit species such as geelbek (Atractoscion aequidens), snoek (Thyrsites atun) and yellowtail (Seriola lalandi) as these are not abundant in their area of operation. Although Cape hake (Merluccius capensis) have previously been caught in the area, participants indicated that they had not been available in the recent past. Kob are reef-associated fish with large home ranges and are known to retreat offshore in winter, returning to inshore waters when the coastal upwelling resumes in summer. ${ }^{4}$ Participants from Melkhoutfontein and Still Bay referred to this migration from the 'outer' to 'inner' reefs throughout. Fishers expect kob to migrate inshore at the start of austral spring for the start of the 'season' and expect the fish to remain in this area until austral autumn.

The observed change in catches and distribution of kob could be attributed to a recent ecosystem regime shift that has taken place in the southern Benguela. The southward and eastward shift of small pelagic fish in the late 1990s to early 2000 s is thought to have been brought about by changes in environmental drivers and subsequently intensified by fishing activities. ${ }^{35}$ This hypothesis has been corroborated by Watermeye ${ }^{36}$ who reported changes in the distributions of predatory fish in the southern Benguela in relation to sardines (Sardinops sagax) and anchovies (Engraulis encrasicolus). Ethnography by Duggan ${ }^{37}$ also indicated changed kob 'behaviour' such as fish not biting, shortened residence time and disruption to migration patterns on the Agulhas Bank as told by fishers from Still Bay. Furthermore, fishing pressure (in the form of by-catch) exerted by the inshore trawl fishery operating in the area could also have contributed to a shortage of kob. The belief that the inshore trawl target kob specifically is exacerbated by a shortage (and near absence) of Agulhas sole (Austroglossus pectoralis) and inshore Cape hake (Merluccius capensis) stocks in the area. ${ }^{38}$ Although changes as a result of fishing pressure are well documented, ${ }^{38,39}$ the degree and extent of climate-induced changes and their influence on local stock abundance remain uncertain.

\section{Policy and regulation}

Policy and the regulation thereof (including enforcement and implementation of policy and regulation) was viewed as the most important stressor in the human-social component of the fishing system and participants expressed continual negative experiences when dealing with policy and regulatory issues.

The Marine Living Resources Act (MLRA) uses a fishery-specific, individual rights allocation system to regulate certain fisheries in South Africa. The domestic industry was initially divided into the recreational, commercial and subsistence sectors. ${ }^{40}$ Rights were given for the commercial and subsistence sectors with recreational fishery regulated through the issuance of annual permits with specific catch restrictions and the prohibition to sell catches. These rights are statutory permissions granted by the minister to harvest specified marine resources for a period of time (see section 18(6) of the Act). ${ }^{6,41}$ The current cohort of traditional handline fishers was granted medium-term rights valid for a period of 8 years that expired at the end of 2013, after which they had to re-apply for rights. The fieldwork for this study took place during this re-application process (termed FRAP 2013). As the previous allocation process had been fraught with inconsistencies and allegations of unfair practice, from the outset, participants did not view the application process in a positive light.

The 'Draft revised Traditional Linefish Policy on the allocation and management of fishing rights: 2013' provided the policy framework for FRAP 2013. This policy sets out two groups of criteria for allocation. Evaluation (exclusionary) criteria seek to exclude anyone who in the current cycle did not comply with regulations set out in the permit conditions. Examples of these evaluation criteria include whether someone is deemed to pose a so-called 'paper quota risk'; whether there is more than one right per household; whether use has been made of a currently allocated right; and whether someone has not been personally involved in the harvesting of the resources as a rights holder and/or cannot prove access to a fishing vessel..$^{42}$ The second set of criteria - balancing criteria - calls for the evaluation of applications by means of a weighting system in order to allow for an assessment of the strength of individual applications. The first balancing criterion is transformation of the fishery for which previously disadvantaged applicants were scored positively. The degree of investment made in the fishery by the applicant in terms of, for example, vessels, equipment and fish-processing initiative, was evaluated next. The third balancing criterion seeks to reward the use of traditional wooden deck boats (less than $10 \mathrm{~m}$ ) if a good performance history could be demonstrated. Past fishing performance, job creation demonstrated by the applicant, historical involvement and reliance on fishing, were all evaluated and scored positively. Lastly, applicants were also scored positively if they had been resident in a traditional fishing village for at least the 10 previous years. ${ }^{42}$ Balancing criteria were a source of immense ire for most participants. These frustrations largely related to practical arrangements preceding the allocation. The requirement to provide evidence of compliance created the perception that the process was unnecessarily laborious. Participants felt that the forms were too long, not available in all official languages and did not cater for differing literacy levels. DAFF personnel were not available to explain the forms and assist with the completion. Whilst applicants could in principle have travelled to the regional DAFF office in Mossel Bay to obtain help, not all participants had the means to travel that distance (anything between $46 \mathrm{~km}$ and $156 \mathrm{~km}$ ).

The second and more pertinent set of frustrations was the requirements set by the balancing criteria themselves. Many believed that the criteria should not have been applicable to them, as they did not operate large enterprises or generate enough income to be placed in a position in which they could implement these measures. Participants highlighted the requirement for skippers/boat owners to contribute towards pension funds and medical aid schemes for crew members as one such measure. It was noted that even if these measures were implemented, the nature of the fishery made the implementation nearly impossible to manage. Various skippers indicated that although they had previously set up saving plans for crew members, their crew often failed to manage their plans and let them lapse when moving between boats. The ensuing discussion with skippers and crew alike indicated a generally held opinion that the implementation and administration of pension aid schemes and the like should be centrally managed and not rest with individual right holders. 
Issues highlighted around the balancing criteria may be a symptom of another underlying problem. This fishery is currently regulated as a commercial fishery ${ }^{6}$ despite displaying characteristics of a smallscale fishery. The formal regulation of small-scale fisheries is a new development in the South African policy landscape. The small-scale fisheries policy (№. 247 of 2012) currently in its early implementation phase, seeks to regulate small-scale and subsistence fisheries. The policy marks a paradigm shift towards a people-centred governance approach in the small-scale fishery. The policy attempts to address social justice issues raised by stakeholders by recognising the role that marine resources could play in poverty alleviation, economic development and the realisation of human rights in South Africa ${ }^{43}$ and signals a move away from the individual rights-based approach to community-centred approaches in various small-scale fisheries. ${ }^{43}$ Provision is made for current (individual) commercial rights holders to apply to be part of the community-based rights although current rights holders will be required to relinquish their individual rights if successful. It is important to note that the intention is for the community allocation to fall within the laid down total applied effort of the linefishery to avoid an increase in overall catch effort. Whether this aim will be successful remains unclear and communities may need to consider alternative livelihood activities to ensure sustainability (see Gammage et al. ${ }^{8}$ )

The conversations surrounding fishing rights have a distinct political slant. Regulatory frameworks and policies place emphasis on the transformation of the industry to include previously disadvantaged persons with a focus on traditional fishers. The term 'traditional' appears to be reserved for South Africans who are classified as being previously disadvantaged, effectively leading to the exclusion of fishers who, although Caucasian, have a strong family history with the fishing sectors in question. These fishers thus assume that they will be excluded from the community-based rights allocation process.

The current management structure is a significant contributory factor to many of the policy-related stressors highlighted. To obtain and keep rights, fishers are expected (as per balancing criteria) to prove continual investment in the fishery and their crew which can add an additional cost burden in a system that is already under increasing pressure because of resource scarcity, natural system variability, the regulatory framework and competition within and among fishing sectors. In comparison to other larger-scale fishing sectors operating in the area, handline fishers are not able to compete in terms of tonnage delivered, are unable to ensure consistent supply of fish, have inadequate storage facilities, and have little access to distribution routes and offset points. A historical overview of the economic conflicts in the fisheries of the South African southeast coas ${ }^{44}$ shows that this 'conflict' is part of the historical context of the fisheries in the area.

These results show that the small-scale commercial linefishery in the area is effectively operating within a policy gap or vacuum as none of the current policies promulgated caters for their specific sectoral needs, making it extremely difficult for fishers to comply with the 'balancing criteria' that have been set out. The inability to manage this fishery in a sustainable manner may ultimately force the current commercial fishers out of the linefishery, and therefore they will be unable to meet the criteria when renewing rights. However, to date, the fishery continues to operate despite all indications that some regulatory issues have a historical context, pointing to some resilience of this fishery.

\section{Interactions with the inshore trawl sector}

The inshore trawl fishery reportedly has a severe impact on the linefishery, ranging from impacts on kob stocks to modification of the benthic habitat, with specific reference to reef health and the impact that discards have on the marine environment. The inshore trawl fishery and ensuing issues evoked some of the most emotional responses from fishers, thus reiterating the historical conflict between the two fisheries. ${ }^{44,45}$

The South African inshore trawl fishery was pioneered at the start of the 20th century as a mixed fishery and operates mainly between Cape Agulhas and the Great Kei River at the eastern boundary of the
Agulhas Bank (and east of our study area), targeting hake and Agulhas sole. ${ }^{45,46}$ Vessels are limited to a maximum length of $30 \mathrm{~m}$ and are excluded from fishing in bays; trawling has in the past generally taken place at depths of $80-110 \mathrm{~m} \cdot{ }^{45}$ Trawl catches are diverse and landings include several non-target species, such as kob, as bycatch. ${ }^{45,47}$ Although recent indications are that the inshore Cape hake and Agulhas sole stocks on the Agulhas Bank are not showing signs of collapse, the impact the sector has on the populations of 'joint product' species, particularly juvenile kob, remains a cause for concern for many of the participants. ${ }^{45,48}$

At the time of this study, the current total allowable catches prescribed for the inshore trawl fishery only included tonnage for the target catch, with no limit set on the amount of by-catch that may be landed. It is indicated that $42 \%$ of the total catches landed were fish species other than hake or sole, with a large portion of this by-catch marketable, with a value that comprises $1-30 \%$ of the total product value. ${ }^{45}$ The linefishery, although not regulated by a total allowable catch, has strict minimum landing size limits imposed on kob, whereas no such restriction exists for the inshore trawl fishery. Scientific data suggest that while the catch quantities for kob and the inshore trawl sector are similar, most of the catches landed by the inshore trawl sector are undersize when considered in terms of the minimum landing size determined for the handline sector.

Participants expressed strong opinions that the inshore trawl are targeting kob. This perception has only recently been verified by data obtained from observer records and resource surveys. ${ }^{44,49}$ Kob stock abundance predictions ${ }^{39}$ suggest that kob stocks have displayed a small amount of recovery on the southern coast between 1987 and 2011, although the stock is still regarded as overexploited. However, this recovery is not reflected in the experiences of the participants, as they have recorded some of the worst catches in recent years. Most participants link the declining catches to inshore trawl activities, although some have also indicated that variations in SST may play a role in fish abundance and/ or availability. Given the historical conflict between the two sectors, it is important to question whether participants are giving other stressors adequate consideration when attributing blame for declining catches.

The matter of by-catch in the inshore trawl industry is currently receiving attention from scientists and managers alike. Greenston ${ }^{38}$ assessed whether an individual transferable quota system could be used to manage the inshore trawl industry on the south coast and suggested that precautionary upper catch limits be assigned to either clusters of boats or rights holders as a way to implement the individual transferable quota system in an attempt to more effectively manage by-catch. The implementation of a precautionary upper catch limit for the fishery is currently in pilot phase..$^{50}$ Whilst this implementation may increase overall ecological sustainability of inshore trawling, it is unclear whether a reduction of technical interactions will be noticed and acknowledged by the linefishery over the longer term, given the resource scarcity experienced.

Participants also indicated that trawlers are landing catches from the outer reefs before kob can migrate towards the coast in austral spring and are thus interfering with their natural migratory pattern. It becomes clear from discussions that there is some overlap in the area of operation for these fisheries. ${ }^{44,45}$ Attwood et al. ${ }^{45}$ indicate that the extent of the overlap between the two fisheries is not fully understood and suggest that there may be a seasonal separation in catches between the two fisheries. ${ }^{44,51}$ The seasonal offshore-inshore migration of kob does play a role in the availability of kob to both the trawl and handline industry with trawled kob catches higher in the winter months and inshore handline catches higher in summer. ${ }^{51}$ Noteworthy is that linefishers have increased their range by buying bigger boats which increases the possible areas of overlap in a situation in which the competition for kob is escalating.

Participants also expressed their concern regarding the impact of trawling on the greater marine and fishery system. Trawling, specifically bottom trawling, impacts on biological and structural levels of the natural system by altering habitat structure and complexity. The reduction of habitat complexity can result in increased predation on juveniles of harvested species as places of refuge for juveniles are reduced. Although the long- 
term effects and impacts of repeated trawling and recovery time are not well documented ${ }^{52}$, the existence of the long-term effects and impacts of trawling has been established for South African waters ${ }^{53}$. Comparative studies between unfished and heavily trawled areas in the Gulf of Mexico have demonstrated that the direct removal of biological (e.g. sponges and anemones) and sedimentary (e.g. sand waves and depressions) structures results in a reduction in habitat complexity. ${ }^{52}$ Failure to resolve issues around 'joint product' will lead to further conflict among the handline and inshore trawl fisheries in the area.

\section{Stressors less mentioned}

Stressors less mentioned by participants, such as the impact of inadequate infrastructure (Table 2), are linked directly to social and economic conditions. It is critically important to develop an understanding of the interactions not only of changes in the physical environment but also of social, economic, cultural and political changes that occur at multiple temporal and spatial scales. ${ }^{22,54-56} \mathrm{Hjerpe}$ and Glaas $^{57}$ state that the omission of socio-economic stress leads to critical weakness in local adaptation strategies. It is important to recognise that while fewer participants mentioned these stressors, they are of no less importance than those stressors already discussed.

\section{Economic stressors}

The lethargic national economy formed the background to many challenges highlighted by participants as both consumers and fishers. An increase in household costs could be related to both an increase in local desires and expectations and an increase in costs at local (e.g. water, food) and global (e.g. fuel, food, supplies) scales. ${ }^{56}$ Whilst input costs and the cost of living are constantly rising, the price of kob per kilo had stayed constant over the preceding 5 years. The fish price is determined by intermediaries who buy the fish from the fishers and resell it, and not by the fishers who carry the input costs. This is not only true for this group of fishers, but also for fishers in other areas of the world. Tuler et al. ${ }^{54}$ comment in relation to fishers who participate in commercial fishing activities in New England (USA) that fuel insurance, gear and bait costs have all increased whilst fish prices have remained constant. A study conducted in Thailand describes a similar situation, namely that incomes in coastal communities are not keeping up with rising costs. ${ }^{56}$

The retail price of some alternative target species is considerably lower than that of kob, and input costs to harvest these species are significantly higher. This disparity is particularly applicable to silvers, which are harvested about $30 \mathrm{~km}$ away from port. High start-up costs make it difficult for new entrants - boats and motors are expensive, a towing vehicle is required for ski boats, and most fishers do not have the necessary capital at their disposal. Banks are unwilling to lend money to fishers who do not have a consistent income because of legislation that requires proof of steady income, making it difficult to access credit from banks.

Many participants indicated that they have borrowed money for fuel and bait from intermediaries operating in the area. This lending adds to an already perilous situation - many were not landing decent catches and did not necessarily make enough to cover running costs to sustain livelihoods. Repaying loans places an additional burden on the skipper/ boat owner, as they bear sole responsibility for running costs. One middleman maintained that he lent money to fishers in cognisance of the fact that he would not have any product to sell if fishers were unable to go to sea.

Fishers operating boats with diesel engines feel that they are in a better position than the fishers operating ski boats with outboard motors, as diesel is subsidised by the government via a tax deduction and petrol is not. However, this saving could be offset, because despite the use of a diesel engine being cheaper on a day-to-day basis, maintenance is costlier. Many participants indicated that their financial situation resulted in the neglect of regular maintenance, which led to major defects that they were unable to repair themselves and cessation of their fishing activities until repairs had been carried out. This decision-making results in individuals and households becoming more vulnerable to stressors in the biophysical environment over longer time periods. ${ }^{45}$

\section{Socio-economic stressors}

Poverty and fisheries are intrinsically linked when dealing with a development discourse in which the enduring narrative is that 'people are poor because they fish' with a dependence on fishing seen as a cause of poverty. However, no clear and systemic relationship between poverty and fisheries has yet been defined for the southern Cape region and fishery households are not necessarily the poorest of the poor. ${ }^{48}$ Small-scale fishing (in particular) is a livelihood that is characterised by a tradition of adapting to changes in both social and natural environments. ${ }^{58}$ Today, rural coastal communities are subject to new types of social and economic pressures. ${ }^{58}$ Possible effects from additional socioeconomic pressures become increasingly clear when considering Vermaaklikheid and, to a lesser extent, Melkhoutfontein. Vermaaklikheid and Melkhoutfontein are previously disadvantaged communities in which the influence of apartheid on the spatial development of the South African landscape is apparent. ${ }^{59}$ Prevailing socio-economic conditions in these communities are not always favourable, and there is a large dependence on government grants and services. There are some important contrasts and similarities between the two communities, with the Vermaaklikheid community being the most similar to a stereotypical fishing community. ${ }^{60}$

Vermaaklikheid (population approximately 400) has only two untarred access roads and is situated a fair distance $(42 \mathrm{~km})$ from its closest economic hub, Riversdale. In contrast, the town of Melkhoutfontein is considerably bigger (population approximately 2500), and geographically closer $(11 \mathrm{~km})$ to its closest economic hub, Still Bay, with greater accessibility to infrastructure in terms of access roads and transport. Census 2011 data from the two towns indicate lower education levels in Melkhoutfontein and Vermaaklikheid when compared to the other towns in the research area. Remote rural areas may be typified by high transaction costs, transport and communications systems that are impaired, the limitation or absence of access to markets and a low provision of government services and infrastructure. ${ }^{61}$ This is reflected in the case of Vermaaklikheid, as all the stressors mentioned by participants align with these general categories. It is clear from the interviews that factors arising from the geographical location and infrastructure of Vermaaklikheid have a distinct impact on the socio-economic conditions and day-to-day functioning of the community. These factors include a lack of access to public services and transport, no easy access to shops and no public schools (although a privately funded school has been established by one of the residents to provide this service to the community). These characteristics may be true for all the communities in the region to a certain extent as the distance to the nearest metropolis $(\sim 400 \mathrm{~km})$ also lends a certain amount of remoteness to the area, with the interaction between the region and the metropolis pointing to a classic core-periphery pattern. ${ }^{62}$

The relative remoteness of the area also influences available formal and informal job opportunities. Although official statistics show that the unemployment rate in the area is lower than national and provincial averages, it must be noted that unemployment statistics only consider active job seekers. Fishers who are not fishing are not necessarily actively seeking other employment and do not necessarily regard themselves as being unemployed or a job seeker. These employment statistics do not take discouraged work seekers and those who are surviving on government grants into account, thus the unemployment rate is likely to be higher than the official rate.

\section{Conclusion: The necessity of a systems approach on a small scale}

Single stressors and their impacts at a localised scale on fishers in a geographically distinct, but relatively small, area of the southern Cape are described here. Although detailed interactions and inter-relationships of the various stressors highlighted remain unclear at present, it is possible to highlight some examples of multiple-stressor interactions that have become apparent through the research process. 
Increases in the fuel price lead to a decrease in disposable income and affect the fishers' ability to carry out maintenance on their boats. This in turn may lead to a compromise in safety standards, resulting in an increased susceptibility to weather stressors, for example if the engine is not performing optimally, navigation of the boat under difficult sea conditions is impaired. In this case, an economic stressor has effectively resulted in a safety stressor, thereby making fishers and their crew more vulnerable to weather stressors. However, the increased input costs such as fuel also have a dampening effect on effort and may lead to a reduction of overfishing. Decreased effort may lead to a decrease in income and thus the economic situation of the fisher and crew may continually worsen in the absence of other income-generating opportunities.

The fishers from Mossel Bay operate deck boats and have overcome overfishing challenges in their immediate area of operation by increasing their range. The bigger boats allow these fishers to operate in rougher sea conditions, but they also require a longer window of good weather because fishers stay at sea for several days in a single trip. The overfishing stressor has thus led to a novel vulnerability to weather conditions on the scale of multiple days, putting additional pressure on fish stocks previously not exploited by this sector. By increasing their ranges, the linefishery is overlapping with the inshore trawl fishery, further fuelling the long-standing conflict between the two fisheries.

The two examples above highlight the complexity of the fishery system in the southern Cape and illustrate how multiple stressors and feedback loops at various scales can interact to form a complex system at various geographical scales. Although it was not within the scope of this study to investigate all these linkages and interactions, the examples of multistressor interactions highlighted are an indication that the interactions found and described by Bennett et al. ${ }^{56}$ also exist in the South African context. Strategies put in place in response to stressors discussed here are further examined in Part 2, Gammage et al. ${ }^{8}$

\section{Acknowledgements}

The South African Research Chair Initiative, funded by the Department of Science and Technology and administered by the National Research Foundation (South Africa), provided bursary and research funding for L.C.G. through the Research Chair in Marine Ecology and Fisheries (A.J.). Our sincere thanks go to all research participants for offering up their time to participate in this project, to Lee-Anne Koller for transcribing the interviews and to the marine ecology and fisheries research group for editorial inputs.

\section{Authors' contributions}

The research was conducted as part of L.C.G.'s MSc, which was cosupervised by A.J. and C.M.

\section{References}

1. Benguela Current Commision. Benguela Current Commission [homepage on the Internet]. c2013 [cited 2016 Jul 15]. Available from: http://www. benguelacc.org/index.php/en/about/the-bclme

2. Hutchings L, Van der Lingen CD, Shannon LJ, Crawford RJM, Verheye HMS, Bartholomae $\mathrm{CH}$, et al. The Benguela Current: An ecosystem of four components. Prog Oceanogr. 2009;83(1-4):15-32. http://dx.doi. org/10.1016/j.pocean.2009.07.046.

3. Jarre A, Hutchings L, Kirkman S, Kreiner A, Tchipalanga P, Kainge P, et al. Synthesis: Climate effects on biodiversity, abundance and distribution of marine organisms in the Benguela. Fish Oceanogr. 2015;24(Suppl 1):122149. http://dx.doi.org/10.1111//fog.12086.

4. Griffiths MH. Long-term trends in catch and effort of commercial linefish off South Africa's Cape Province: Snapshots of the 20th century. S Afr J Mar Sci. 2000;22(1):81-110. http://dx.doi.org/10.2989/025776100784125663.

5. Blamey LK, Shannon LJ, Bolton JJ, Crawford RM, Dufois F, Evers-King H, et al. Ecosystem change in the southern Benguela and the underlying processes. $J$ Mar Syst. 2015;144:9-29. http://dx.doi.org/10.1016/j.jmarsys.2014.11.006.
6. South African Department of Environmental Affairs and Tourism (DEAT). Policy for the allocation and management of commercial fishing rights in the traditional line fishery. Cape Town: DEAT; 2005. p.1-7.

7. Adger WN. Vulnerability. Glob Environ Chang. 2006;16(3):268-281. http:// dx.doi.org/10.1016/j.gloenvcha.2006.02.006.

8. Gammage LC, Jarre A, Mather C. A case study from the southern Cape linefishery 2: Considering one's options when the fish leave. S Afr J Sci. 2017;113(5/6), Art. \#2016-0254, 10 pages. http://dx.doi.org/10.17159/ sajs.2017/20160254.

9. O'BrienK, SygnaL, HaugenJE. Vulnerable orresilient? Amulti-scaleassessment of climate impacts and vulnerability in Norway. Clim Change. 2004:64(12):193-225. http://dx.doi.org/10.1023/B:CLIM.0000024668.70143.80.

10. Bunce M, Brown K, Rosendo S. Policy misfits, climate change and crossscale vulnerability in coastal Africa: How development projects undermine resilience. Environ Sci Policy. 2010;13(6):485-497. http://dx.doi. org/10.1016/j.envsci.2010.06.003.

11. Reid P, Vogel C. Living and responding to multiple stressors in South Africa - Glimpses from KwaZulu-Natal. Glob Environ Chang. 2006;16(2):195-206. http://dx.doi.org/10.1016/j.gloenvcha.2006.01.003.

12. Eakin $\mathrm{H}$, Luers $\mathrm{AL}$. Assessing the vulnerability of social-environmenta systems. Annu Rev Environ Resour. 2006;31(1):365-394. http://dx.doi. org/10.1146/annurev.energy.30.050504.144352.

13. Füssel HM, Klein RJT. Climate change vulnerability assessments: An evolution of conceptual thinking. Clim Change. 2006;75(3):301-329. http://dx.doi. org/10.1007/s10584-006-0329-3.

14. Ziervogel G, Calder R. Climate variability and rural livelihoods: Assessing the impact of seasonal climate forecasts in Lesotho. Area. 2003;35(4):403-417. http://www.jstor.org/stable/20004345.

15. Eriksen S, Næss L, Klein R, Hammill A, Robledo C, O' Brien K. Portfolio screening for mainstreaming adaptation to climate change. Paper presented at: "Climate or development?"; 2005 October 28-29; Hamburg, Germany.

16. Ziervogel G, Bharwani S, Downing TE. Adapting to climate variability: Pumpkins, people and policy. Nat Resour Forum. 2006;30(4):294-305. http://dx.doi.org/10.1111/j.1477-8947.2006.00121.x.

17. Eriksen S, Silva J. The vulnerability context of a savanna area in Mozambique: Household drought coping strategies and responses to economic change. Environ Sci Policy. 2009;12(1):33-52. http://dx.doi.org/10.1016/j. envsci.2008.10.007.

18. O'Brien KL, Leichenko RM. Double exposure: Assessing the impacts of climate change within the context of economic globalization. Glob Environ Chang. 2000;10:221-232. http://dx.doi.org/10.1016/S0959-3780(00)00021-2.

19. Turner B, Kasperson R, Matson PA, McCarthy JJ, Corell RW, Christensen A, et al. A framework for vulnerability analysis in sustainability science. Proc Natl Acad Sci USA. 2003;100(14):8074-8079. http://dx.doi.org/10.1073/ pnas. 1231335100

20. Cutter SL, Barnes L, Berry M, Burton C, Evans E, Tate E, et al. A placebased model for understanding community resilience to natural disasters. Glob Environ Chang. 2008;18(4):598-606. http://dx.doi.org/10.1016/j. gloenvcha.2008.07.013.

21. Moloney CL, Fennessy ST, Gibbons MJ, Roychoudhurye A, Shillington FA Von der Heydene BP, et al. Reviewing evidence of marine ecosystem change off South Africa. Afr J Mar Sci. 2013;35(3):427-448. http://dx.doi.org/10.29 89/1814232X.2013.836135.

22. Mead A, Griffiths MH, Branch GM, McQuaid CD, Blamey LK, Bolton J, et al. Human-mediated drivers of change - Impacts on coastal ecosystems and marine biota of South Africa. Afr J Mar Sci. 2013;35(3):403-425. http:// dx.doi.org/10.2989/1814232X.2013.830147.

23. Hutchings L, Jarre A, Lamont T, Van den Berg M, Kirkman S. St Helena Bay (Southern Benguela) then and now: Muted climate signals, large human impact. Afr J Mar Sci. 2012;34(4):559-583. http://dx.doi.org/10.2989/181 4232X.2012.689672.

24. Howard JAE, Jarre A, Clark A, Moloney CL. Application of the sequential t-test algorithm for analysing regime shifts to the southern Benguela ecosystem. Afr J Mar Sci. 2007;29(3):437-451. http://dx.doi.org/10.2989/ AJMS.2007.29.3.11.341. 
25. Blamey LK, Howard JAE, Agenbag J, Jarre A. Regime-shifts in the southern Benguela shelf and inshore region. Prog Oceanogr. 2012;106:80-95. http:// dx.doi.org/10.1016/j.pocean.2012.07.001.

26. Perry RI, Barange M, Ommer RE. Global changes in marine systems: A social-ecological approach. Prog 0ceanogr. 2010;87(1-4):331-337. http:// dx.doi.org/10.1016/j.pocean.2010.09.010.

27. Ommer RE, Perry RI, Neis B. Bridging the gap between social and natural fisheries science: Why is this necessary and how can it be done? In: Nielsen J, Dodson JJ, Friedland K, Hamon TR, Musick J, Verspoor E, (editors). Reconciling fisheries with conservation: Proceedings of the Fourth World Fisheries Congress. Symposium 49. Bethesda, MD: American Fisheries Society; 2008. p. 177-185.

28. Jarre A, Ragaller, SM, Hutchings L. Long-term, ecosystem-scale changes in the southern Benguela marine pelagic social-ecological system: Interaction of natural and human. Ecol Soc. 2013;18(4), Art. \#55, 15 pages. http://dx.doi. org/10.5751/ES-05917-180455.

29. Solomon S, Qin D, Manning M, Chen Z, Marquis M, Avery KB, et al, editors. Contribution of Working Group I to the Fourth Assessment Report of the Intergovernmental Panel on Climate Change. Cambridge, UK and New York: Cambridge University Press; 2007. p. 1-996.

30. Bennett NJ, Dearden P, Murray G, Kadfak A. The capacity to adapt?: Communities in a changing climate, environment, and economy on the northern Andaman coast of Thailand. Ecol Soc. 2014;9(2), Art. \#5, 20 pages. http://dx.doi.org/10.5751/ES-06315-190205

31. Rouault M, Penven P, Pohl B. Warming in the Agulhas Current system since the 1980's. Geophys Res Lett. 2009;36(12):2-6. http:// dx.doi/10.1029/2009GL037987.

32. Rouault M, Pohl B, Penven P. Coastal oceanic climate change and variability from 1982 to 2009 around South Africa. Afr J Mar Sci. 2010;32(2):237-246. http://dx.doi.org/10.2989/1814232X.2010.501563.

33. Roy C, Van der Lingen C, Coetzee J, Lutjeharms J. Abrupt environmental shift associated with changes in the distribution of Cape anchovy Engraulis encrasicolus spawners in the southern Benguela. Afr J Mar Sci. 2007;29(3):309-319. http://dx.doi.org/10.2989/AJMS.2007.29.3.1.331.

34. Perry RI, Ommer RE. Scale issues in marine ecosystems and human interactions. Fish Oceanogr. 2003;12(4/5):513-522. http://dx.doi. org/10.1046/j.1365-2419.2003.00254.x.

35. Coetzee JC, Van der Lingen C, Hutchings L, Fairweather T. Has the fishery contributed to a major shift in the distribution of South African sardine? ICES J Mar Sci. 2008;65(9):1676-1688. http://dx.doi.org/10.1093/icesjms/fsn184.

36. Watermeyer K. Ecosystem implications of the recent southward shift of key components in the southern Benguela [PhD thesis]. Cape Town: University of Cape Town; 2015. Available from: http://www.eafsa.uct.ac.za/publications-2015.

37. Duggan GL. In the realm of the Kob Kings: Rethinking knowledges and dialogue in a small-scale fishery [master's dissertation]. Cape Town: University of Cape Town; 2012. Available from: http://hdl.handle.net/11427/11942.

38. Greenston J. Assessing the suitability of an individual transferable quota system to address unregulated by-catch in South Africa's inshore trawl fishery [master's dissertation]. Cape Town: University of Cape Town; 2013. Available from: http://hdl.handle.net/11427/4749.

39. Winker H, Kerwath SE, Attwood CG. Report on age-structured stock assessments and the simulation of the impacts of various fisheries management options for the South African linefishery. Report no. LSWG II. Cape Town: Department of Agriculture, Forestry and Fisheries; 2014.

40. Van Sittert L, Branch G, Hauck M, Sowman M. Benchmarking the first decade of post-apartheid fisheries reform in South Africa. Mar Policy. 2006;30(1):96110. http://dx.doi.org/10.1016/j.marpol.2005.06.012.

41. Marine Living Resources Act (Act No. 18 of 1998) of South Africa.

42. South African Department of Agriculture, Forestry and Fisheries (DAFF). Draft revised traditional linefish policy on the allocation and management of fishing rights: 2013. Cape Town: DAFF; 2013. p.1-14.

43. Sowman M, Sunde J, Raemaekers S, Schultz O. Fishing for equality: Policy for poverty alleviation for South Africa's small-scale fisheries. Mar Policy. 2014;46:31-42. http://dx.doi.org/10.1016/j.marpol.2013.12.005
44. Visser $N$. The origins of the present: Economic conflicts in the fisheries of the South African south east coast, circa 1910 - 1950. Marit Stud. 2015;14(1):9. http://dx.doi.org/10.1186/s40152-015-0029-6

45. Attwood CG, Petersen SL, Kerwath SE. Bycatch in South Africa's inshore trawl fishery as determined from observer records. ICES J. Mar. Sci. 2011;68(10):2163-2174 http://doi.dx.org/10.1093/icesjms/fsr162

46. South African Department of Environmental Affairs and Tourism (DEAT). General policy on the allocation and management of long term commercial fishing rights. Cape Town: DEAT; 2005. p.1-48.

47. Walmsley SA, Leslie RW, Sauer WHH. Bycatch and discarding in the South African demersal trawl fishery. Fish Res. 2007;86(1):15-30. http://dx.doi. org/10.1016/j.fishres.2007.03.002

48. Anderson R, Auerswald L, Butterworth D, Cockcroft A, Cooper R, Coetzee J, et al. Status of the South African marine fishery resources. Cape Town: Department of Agriculture, Forestry and Fisheries; 2014. p.1-77.

49. South African Department of Agriculture, Fisheries and Forestry. 2009 Performance review of fishing right holders - Clusters C \& D. Cape Town: DAFF; 2012. p.1-85.

50. Greenston JD, Attwood, CG. Assessing the feasibility of a bycatch comanagement programme in South Africa's inshore trawl fishery [document on the Internet]. c2013 [cited 2016 Nov 24]. Available from: http://www. rfalliance.org.za/wp-content/uploads/2014/09/RFA-Bycatch-ManagementReport.pdf

51. Attwood C, Booth T, Kerwath S, Mann B, Marr S, Bonthuys J, et al., editors. A decade after the emergency: Proceedings of the 4th LineFish Symposium. WWF South Africa Rep Series - 2013/Marine/001. Cape Town: WWF South Africa; 2013.

52. Grekov AA, Pavlenko AA. Comparison of the longline and trawl groundfish fishery in the Barents Sea to develop proposals for the sustainable use of the marine bio-resources in the Barents Sea. Moscow-Murmansk: The World Wildlife Fund; 2011.

53. Atkinson LJ, Field J, Hutchings L. Effects of demersal trawling along the west coast of southern Africa: Multivariate analysis of benthic assemblages. Mar Ecol Prog Ser. 2011;430:241-255. http://dx.doi.org/10.3354/meps08956.

54. Tuler S, Agyeman J, Da Silva PP, LoRusso KR, Kay R. Assessing vulnerabilities: Integrating information about driving forces that affect risks and resilience in fishing communities. Hum Ecol Rev. 2008;15(2):171-184.

55. Perry RI, Ommer RE, Barange M, Jentoft S, Neis B, Sumaila UR. Marine social-ecological responses to environmental change and the impacts of globalization. Fish Fisheries. 2011;12(4):427-450. http://dx.doi.org/10.1111/ j.1467-2979.2010.00402.x

56. Bennett NJ, Dearden P, Peredo, AM. Vulnerability to multiple stressors in coastal communities: A study of the Andaman coast of Thailand. Clim Dev. 2015;7(2):37-41. http://dx.doi.org/10.1080/17565529.2014.886993.

57. Hjerpe M, Glaas E. Evolving local climate adaptation strategies: Incorporating influences of socio-economic stress. Mitig Adapt Strateg Glob Chang. 2012;17(5):471-486. http://dx.doi.org/10.1007/s11027-011-9337-3.

58. Salmi P. Rural pluriactivity as a coping strategy in small-scale fisheries. Sociol Rural. 2005;45(1-2):22-36. http://dx.doi.org/10.1111/j.14679523.2005.00288.x

59. Lemon A. The apartheid city. In: Lemon A. Homes apart: South Africa's segregated cities. Cape Town: David Philip; 1991. p.1-26.

60. Isaacs M. A social coastal fisheries policy for South Africa? Subsistence fisheries co-management for sustainable livelihoods and poverty alleviation. PLAAS Policy Brief no. 24. Cape Town: PLAAS; 2006. p. 1-8.

61. Béné C, Friend RM. Poverty in small-scale fisheries: Old issue, new analysis. Prog Dev Stud. 2011;11(2):119-144. http://dx.doi. org/10.1177/146499341001100203

62. Baldwin R, Forslid R, Martin P, Otaviano GIP, Robert-Nicoud F. The coreperiphery model: Key features and effects. Brakman S, Heijdra BJ, editors. In: The monopolistic competition revolution in retrospect. New York: Cambridge University Press; 2004. p. 213-235. 